This item was submitted to Loughborough's Research Repository by the author.

Items in Figshare are protected by copyright, with all rights reserved, unless otherwise indicated.

\title{
The dimensionality of the market orientation construct
}

PLEASE CITE THE PUBLISHED VERSION

https://doi.org/10.1080/0965254X.2019.1677747

PUBLISHER

Taylor \& Francis (Routledge)

VERSION

AM (Accepted Manuscript)

PUBLISHER STATEMENT

This is an Accepted Manuscript of an article published by Taylor \& Francis in Journal of Strategic Marketing on 10 October 2019, available online: http://www.tandfonline.com/10.1080/0965254X.2019.1677747.

\section{LICENCE}

CC BY-NC-ND 4.0

\section{REPOSITORY RECORD}

Crick, Jim. 2019. "The Dimensionality of the Market Orientation Construct". Loughborough University. https://hdl.handle.net/2134/37655. 


\title{
THE DIMENSIONALITY OF THE MARKET ORIENTATION CONSTRUCT
}

\begin{abstract}
Market orientation is the implementation of the marketing concept and the organisation-wide creation of customer value. While there have been various conceptualisations and operationalisations of the market orientation construct, marketing academics have focused on a set of information-processing activities that managers and employees use to create a superior customer value provision to competitors. Moreover, although most researchers have studied market orientation as a multi-dimensional construct, others have used uni-dimensional approaches. In this literature review, the different approaches of market orientation are explored; plus, some recommendations are made about why marketing academics should not study market orientation as a uni-dimensional construct (based on conceptual and operational problems). That is, regardless of whether scholars investigate market orientation as a corporate culture or a set of firm-level behaviours (among other forms), there are several facets of the market orientation construct. This paper ends with some directions for future research.
\end{abstract}

Key words: Market orientation; customer value; marketing concept, entrepreneurial marketing.

\section{Introduction}

One of the most important questions that marketers seek to answer is: how can companies create value for their customers (Woodruff, 1997; Ryals, 2005; Kumar \& Reinartz, 2016)? Marketing theory has suggested that if organisations can create value for their customers, their performance (e.g., sales) is likely to be increased (Slater, 1997; Morgan, 2012; Hult \& Ketchen Jr., 2017). Customer value can be assessed in numerous capacities, such as low prices or firms providing a good or service in a responsive manner that minimises customers' inconvenience (Parasuraman, 1997; Payne \& Holt, 2001; Jaakkola \& Alexander, 2014). The marketing concept is a business philosophy surrounding the objective of marketing activities being to create value for customers in ways that competitors cannot imitate (Kohli \& Jaworski, 1990; O'Cass, 2001; Jones \& Shaw, 2018). Yet, in competitive business environments, some entities might struggle to create a superior customer value provision to their competitors, especially organisations with few resources and capabilities (Hunt \& Morgan, 1995). 
With there being numerous ways to implement the marketing concept, the notion of market orientation is used to help firms to create value for their customers (Ellis, 2006). Market orientation has been: defined, conceptualised, and operationalised in various ways (Kirca, Jayachandran, \& Bearden, 2005; Cadogan, Kuivalainen, \& Sundqvist, 2009), but a common theme within the marketing literature is that market-oriented companies exhibit behaviours that are consistent with the marketing concept (reference withheld). Despite the market orientation construct being well-studied, a major problem pertains to such theory. That is, there is evidence to suggest that certain scholars have not fully-appreciated the dimensionality of the market orientation construct (e.g., Deng \& Dart, 1994; Deshpande \& Farley, 1998; Morgan, Anokhin, Kretinin, \& Frishammar, 2015). Henceforth, the objective of this paper is to help marketing scholars to appreciate the dimensionality of the market orientation construct. With such research, recommendations can be made to marketing academics about the best ways to study the different facets of market orientation (e.g., as a corporate culture or a set of firm-level behaviours).

Interestingly, market orientation has been linked with other stands of literature. For example, the marketing/entrepreneurship interface (also known as entrepreneurial marketing) has experienced a great deal of attention, in which various studies have examined its dimensions (e.g., Hills, Hultman, \& Miles, 2008; Morrish, Miles, \& Deacon, 2010; Crick \& Crick, 2018). While the marketing/entrepreneurship interface examines the interplay between the forces of market orientation and entrepreneurial orientation (Miles \& Arnold, 1991), entrepreneurial marketing has been studied as seven-component construct, comprised of: a proactive orientation, opportunity-driven behaviours, a customer intensity, innovation-focused behaviours, risk management activities, and value creation (Morris, Schindehutte, \& LaForge, 2002; Miles, Gilmore, 
Harrigan, Lewis, \& Sethna, 2015; O’Cass \& Morrish, 2016). Yet, it could be argued that entrepreneurial marketing theory has progressed slightly too quickly, in which prior research should have been conducted more thoroughly on the dimensionality of the market orientation construct before linkages with other strategic orientations (e.g., entrepreneurial orientation) were studied.

Further, although there has been research suggesting reasons why market orientation should no longer be investigated (such as there being too many papers in circulation) (see Henderson, 1998), the dimensionality of the market orientation construct should be studied to help marketing academics to strengthen their understanding of the variable that they are attempting to explore. Thus, this article sheds light on the different forms of market orientation, namely: corporate cultural forms, behavioural forms, international forms, and other (lesser-known) forms and comments on the different facets of the construct under these approaches (see Narver \& Slater, 1990; Ruekert, 1992; Jaworski \& Kohli, 1993; Homburg \& Pflesser, 2000; Cadogan, Diamantopoulos, \& Siguaw, 2002; Jones \& Rowley, 2011). Therefore, this literature review is divided into the following three sections. First, the market orientation literature is reviewed to include an overview of its history, as well as the different forms of the construct (as per the above). Second, some directions for future research are highlighted to help marketing scholars to understand the dimensionality of the market orientation construct. Third, this article is concluded.

\section{Framing literature}

\section{A brief history of market orientation}

A key milestone in the marketing literature was 1990, in which two seminal papers were published in the Journal of Marketing, both examining what it means for 
companies to be market-oriented (see Kohli \& Jaworski, 1990; Narver \& Slater, 1990). Kohli \& Jaworski (1990) took a qualitative approach by interviewing a large sample of senior managers in the United States about the: dimensions, antecedents, and consequences of market orientation. They found that market orientation concerns the organisation-wide: generation of, dissemination of, and responsiveness to market intelligence (Diamantopoulos \& Hart, 1993). After their seminal study, these authors developed and validated the MARKOR scale and used this operationalisation to test the antecedents and consequences of market orientation (see Jaworski \& Kohli, 1993; Kohli, Jaworski, \& Kumar, 1993). These authors studied market orientation as a set of firm-level behaviours, namely: generation, dissemination, and responsiveness activities and highlighted that if organisations manage them correctly, they can improve their performance (e.g., sales) (Cadogan, 2003; Jaworski \& Kohli, 2017).

In addition to Kohli \& Jaworski's (1990) seminal paper, Narver \& Slater (1990) took a quantitative lens and developed and tested a measure of market orientation (the MKTOR scale). From a sample of companies in the United States, these authors found that market orientation is comprised of three dimensions, namely: a competitor orientation, a customer orientation, and inter-functional coordination (Cadogan \& Diamantopoulos, 1995). Narver \& Slater (1990) tested the MKTOR scale and found that higher-levels of market orientation are likely to lead to improvements in business performance (e.g., sales). Unlike Kohli \& Jaworski's (1990) study, Narver \& Slater (1990) conceptualised and operationalised market orientation as a corporate culture (not a set of firm-level behaviours), meaning that a market-oriented organisation is one where all managers and employees believe that customer value creation is likely to be a performance-driving activity (Harris, 1998; Homburg \& Pflesser, 2000; Harris \& 
Ogbonna, 2001). Consequently, it is critical to note that there are two opposing views to studying market orientation, i.e., corporate cultures versus firm-level behaviours.

Although many marketing academics credit 1990 as being the year that the market orientation construct was formally conceptualised and operationalisation, market orientation can be traced back to the 1950s (reference withheld). Indeed, several of these earlier papers examined market (or marketing) orientation tangentially, such as exploring the role of marketing business functions and how companies create value for their customers while managing the financial constraints of investing resources (e.g., cash) towards other departments (Bund \& Carroll, 1957; McNamara, 1972; De La Torre \& Toyne, 1978; Blois, 1980; Ruekert \& Walker Jr., 1987). Further, certain pre-1990 market orientation studies examined the marketing concept as a business philosophy linked with creating a superior customer value provision to competitors (e.g., Felton, 1959; Dickinson, Herbst, \& O’Shaughnessy, 1986). Indeed, Kohli \& Jaworski (1990) and Narver \& Slater (1990) built upon some of these earlier studies when developing their respective lenses of the market orientation construct. The link between market orientation and company performance follows in the next section.

\section{Market orientation and company performance}

While the subsequent sections of this literature review will cover the different forms of market orientation in greater detail (i.e., corporate cultures versus firm-level behaviours), it is important to highlight the relationship between market orientation (in a general sense) and company performance. It is appreciated that there are many assessments of company performance, such as: sales revenues, profitability, competitive, advantages, and other financial metrics (Ray, Barney, \& Muhanna, 2004;

Katsikeas, Morgan, Leonidou, \& Hult, 2016). Yet, market orientation has been found 
to be positively-related to a wide variety of performance outcome variables, with very few scholars finding a negative link (Hurley \& Hult, 1998; Kirca et al., 2005; Gaddefors \& Anderson, 2009; Murray, Gao, \& Kotabe, 2011; Hodgkinson, Hughes, \& Hughes, 2012). That is, if organisations successfully create a superior customer value provision than their competitors, they are likely to satisfy the wants and needs of their customers in sync with the themes of the marketing concept (Ruekert, 1992; Morgan, 2012; Kumar \& Reinartz, 2016). As such, market orientation could have a linear (positive) relationship with a variety of company performance outcomes (Stokes, 2000; Ellis, 2006; Olson, Slater, Hult, \& Olson, 2018).

However, certain scholars have examined the non-linear (inverted U-shaped or quadratic) relationship between market orientation and company performance (e.g., Narver \& Slater, 1990; Maltz \& Kohli, 1996). Arguments for studying this link have included that if firms engage in "too little" market orientation, they are unlikely to create a superior customer value provision, for which competitors are likely to obtain stronger positions in their markets (Atuahene-Gima, Slater, \& Olson, 2005). With "too much" market orientation, scholars have argued that market orientation is an expensive process to engage in, as there can be high costs associated with creating value for customers (e.g., market research and advertising) (Slater \& Narver, 1994; Goebel, Marshall, \& Locander, 1998). Thus, if firms invest too heavily in market-oriented activities, they might deplete their resources and under-invest in activities that are not associated with the implementation of the marketing concept (reference withheld). Hence, companies are faced with the challenging task of engaging in an "optimallevel" of market orientation, as it could have a quadratic relationship with company performance (Cadogan et al., 2009). 
Additionally, a large body of knowledge has surrounded the contingencies (moderating factors) that could affect the market orientation - company performance relationship (Han, Kim, \& Srivastava, 1998; Kirca et al., 2005; Ellis, 2006; Kumar, Jones, Venkatesan, \& Leone, 2011). The competitive business environment has been a common contingency, as scholars have argued that in certain market conditions, such as a high-degree of competitive intensity, market orientation is less likely to improve company performance (Ozturan, Ozsomer, \& Pieters, 2014). Interestingly, some academics have found no evidence for the competitive business environment moderating the relationship between market orientation and company performance (e.g., Slater \& Narver, 1994), whereas, others have found that it is a highly-important factor that could help or hinder the performance consequences of market orientation (e.g., Cadogan, Cui, \& Li, 2003). Hence, there appears to be an unsettled debate as to conditions that market orientation is most likely to drive company performance. The role of market orientation within the firm is discussed in the next section.

\section{Market orientation with the firm}

Another issue is that despite there being differing perspectives surrounding the: facets, drivers, and outcomes of the market orientation construct (Cadogan, 2003; Kirca et al., 2005; Ellis, 2006), it has been established that market orientation is an organisation-wide issue. That is, to implement the marketing concept, companies need to be focused about creating a superior-level of customer value than competitors (Kohli \& Jaworski, 1990; O'Cass, 2001). Moreover, customer value creation is not exclusive to one departmental function of an organisation. For example, several studies have investigation the role of the "marketing department" within the firm, arguing that the managers and employees within such functional areas are the most important members of staff that contribute to their business' customer value provision (Verhoef 
\& Leeflang, 2009; Feng, Morgan, \& Rego, 2015). However, the market orientation literature has suggested that although some departments are likely to play integral roles in creating customer value, managers and employees in all areas of their business need to create value for their customers (Narver \& Slater, 1990; Diamantopoulos \& Hart, 1993).

Drawing upon the work of Piercy (1987), organisations might devise business strategies that are intended to create a superior degree of customer value than competitors, but if firms do not have the financial assets to fund such activities, then they are unlikely to succeed in the implementation stage. Henceforth, Piercy (1987) recommended that departmental functions should communicate with one another to make marketing work within the boundaries of companies (e.g., marketing and finance functions). Furthermore, under Narver \& Slater's (1990) conceptualisation and operationalisation of market orientation, inter-functional coordination involves managers and employees, from a range of departmental functions, cooperating to contribute to their firm's customer value provision. Likewise, when Kohli \& Jaworski (1990) defined their dimensions of market orientation, they highlighted that when businesses: generate, disseminate, and are responsive to market intelligence, no single functional area is responsible for market-oriented activities, rather, it is the organisation-wide implementation of the marketing concept (Fang, Chang, Ou, \& Chou, 2014).

Additionally, when companies implement market-oriented activities, there is often an interface with customers to evaluate the extent to which they have created their intended value (Gounaris, Vassilikopoulou, \& Chatzipanagiotou, 2010). However, managers might intend to have a market-oriented organisation, namely, one that prioritises customer value creation, but if their employees do not share the same 
vision, the firm is unlikely to exhibit market-oriented activities at the functional-level (reference withheld). Consequently, marketing scholars should not view market orientation as an exclusively managerial issue. Instead, they should share the opinion that market orientation is developed by managers and employees from across all business functions of a company (Cadogan, 2003). This is especially relevant for businesses that compete in service industries, whereby, functional-level employees have frequent dealing with customers, meaning that they need to engage in customer value-oriented activities to implement the marketing concept (Lemon \& Verhoef, 2016). The link between market orientation and entrepreneurial orientation follows in the next section.

\section{Market orientation and entrepreneurial orientation}

While market orientation is the implementation and the marketing concept and the organisation-wide creation of customer value (Slater \& Narver, 2000; Hult, Ketchen Jr., \& Slater, 2005; Carpenter, 2017), entrepreneurial orientation is a construct used to implement the entrepreneurship concept (Lumpkin \& Dess, 1996; Wiklund \& Shepherd, 2003; Covin \& Miller, 2014). The interplay between the forces of market orientation and entrepreneurial orientation under the marketing/entrepreneurship interface (Hills \& LaForge, 1992; O’Dwyer, Gilmore, \& Carson, 2009; Hills \& Hultman, 2011; Crick, 2018), for which there has been a large volume of studies examining the links between market orientation and entrepreneurial orientation and whether such strategic orientations are positive or negative drivers of company performance (assessed in different capacities) (Matsuno, Mentzer, \& Ozsomer, 2002; Baker and Sinkula, 2009). Entrepreneurial orientation has been conceptualised and operationalised as a multi-dimensional construct, namely, firms': innovative, proactive, risk-taking, autonomous, and competitively aggressive behaviours (Wiklund \& 
Shepherd, 2005; Rauch, Wiklund, Lumpkin, \& Frese, 2009; Sundqvist, Kylaheiko, Kuivalainen, \& Cadogan, 2012; Covin \& Wales, 2018).

Jones \& Rowley (2011) helped to extend research positioned at the marketing/entrepreneurship interface to examine the intersections between: market orientation, entrepreneurial orientation, customer orientation, and innovation orientation. These authors developed a conceptual framework, finding that a firm's entrepreneurial marketing orientation is a construct that "has been created by collapsing existing scales to generate a set of dimensions and by identifying the key dimensions within each orientation" (Jones \& Rowley, 2011, p. 30). They argued that entrepreneurial marketing activities need to be assessed in a context-specific manner, in which the forces of market orientation and entrepreneurial orientation (among other strategic orientations) vary across entrepreneurs in different industries and markets. While this current article does not focus on a businesses' entrepreneurial marketing orientation, it is accepted that market orientation might have conceptual and operational linkages with entrepreneurial orientation (Chaton, 1997; Jones \& Rowley, 2009; Sole, 2013; Crick, 2018). Hence, to better-understand the dimensionality of the market orientation construct, the link between market orientation and entrepreneurial orientation have been considered.

Entrepreneurship scholars appear to be in relative agreement about how to bestconceptualise and operationalise the entrepreneurial orientation variable (Covin \& Slevin, 1989; Wiklund \& Shepherd, 2003; McGee \& Peterson, 2017). Based on the subsequent themes of this article, the same cannot be said for market orientation, with multiple conceptualisations and operationalisations being available to marketing researchers (Lafferty \& Hult, 2001; Cadogan, 2003; Cadogan et al., 2009; Jaworski \& Kohli, 2017). This is important to both pure marketing scholars, as well as those 
working at the marketing/entrepreneurship interface, as limited insights exist surrounding how the entrepreneurial orientation construct can be linked with the disparate approaches of studying the market orientation construct (Jones \& Rowley, 2011). As mentioned earlier, some academics have found that market orientation and entrepreneurial orientation can be complementary for businesses, in terms of their positive link with company performance (e.g., sales) (Baker \& Sinkula, 2009; Boso, Story, \& Cadogan, 2013).

Other scholars, using entrepreneurial marketing theory, have suggested that market orientation and entrepreneurial orientation are not complementary strategic orientations (see Morgan et al., 2015). Perhaps such findings will become clearer if academics can develop stronger insights into how market orientation can be conceptualised and operationalised to evaluate how it links with variables, such as entrepreneurial orientation. Hence, now is an important time to help marketing academics to clarify what it means to be market-oriented, in terms the best ways to conceptualise and operationalise the market orientation construct. Further, by clarifying the dimensionality of the market orientation construct, this article has the additional value of assisting scholars working at the marketing/entrepreneurship interface to better-understand how market orientation relates to entrepreneurial orientation and other entrepreneurial marketing business strategies (and company performance outcomes). In the following section, corporate cultural forms of market orientation are conceptualised.

\section{Corporate cultural forms of market orientation}

As mentioned earlier, Narver \& Slater (1990) used the MKTOR scale to operationalise the market orientation construct as a corporate culture, comprised of: a competitor 
orientation (the extent to which firms are familiar with their competitors' activities, as well as their strengths and weaknesses), a customer orientation (the degree to which businesses are aware of their customers' wants and needs), and inter-functional coordination (the level of communication and cooperation between departmental functions surrounding the creation of customer value) (Cadogan \& Diamantopoulos, 1995). As a corporate culture, Narver \& Slater (1990) argued that all hierarchies should collect and process information about customers and competitors and believe that creating a superior customer value provision to competitors is likely to be a performance-driving activity (Harris \& Ogbonna, 2001; Cadogan, 2003). Hence, according to Narver \& Slater (1990), market-oriented beliefs should be shared by managers and employees alike. Arguably, the MKTOR scale is the most commonlyused measure of market orientation under a corporate cultural lens, for which other authors have extended such approaches (e.g., Harris, 1998).

Other marketing scholars have examined corporate cultural forms of market orientation under different theoretical lenses. For instance, Homburg \& Pflesser (2000) developed and tested a model examining the multiple layers of market-oriented corporate cultures. These authors highlighted that organisations need to have a shared view that market orientation is an important activity to engage in. Homburg \& Pflesser (2000) continued to argue that if managers and employees support this assertion, they are likely to possess: values, norms, and artefacts surrounding the importance of creating superior value for customers. Then, Homburg \& Pflesser (2000) found that these dimensions of a market-oriented corporate culture are likely to yield market-oriented behaviours (as per Kohli et al., 1993), which in turn, could positivelyimpact business performance. Thus, instead of conceptualising and operationalising market-oriented corporate cultures as a three-component variable (as per Narver \& 
Slater, 1990; Slater \& Narver, 1998; Connor, 1999; Lafferty \& Hult, 2001), Homburg and Pflesser (2000) examined a significantly more complex, multi-layer assessment.

Corporate cultures have been conceptualised as appearing like an iceberg (Wines \& Hamilton, 2009). Specifically, using this metaphor, icebergs are gigantic structures, for which the icy mass above the surface of the water is merely a small fraction of the entire structure (Hamley \& Budd, 1986). The same can be said for corporate cultures, whereby, above the surface of the water, there may be traits of an organisational culture that visible to individuals that do not work for the company (an outside-in perspective) (Thompson \& Wildavsky, 1986). While these "visible" traits (e.g., strategies, policies, and structures) might be what managers and employees claim to be the activities that they use to operate their business, there are a range of "invisible" traits that are difficult to observe from an outside-in perspective (Nonaka, 1994). Arguably, these below-the-surface facets of a corporate culture (e.g., unwritten rules, feelings, and shared assumptions) are the ways that managers truly run their companies (Palmer \& Dunford, 1996). Behavioural forms of market orientation follow in the next section.

\section{Behavioural forms of market orientation}

Alongside corporate cultural forms of market orientation, several scholars have examined market orientation as a set of firm-level behaviours pertaining to the implementation of the marketing concept (Kirca et al., 2005; Ellis, 2006; Beneke, Blampied, Dewar, \& Soriano, 2016). The behavioural view of market orientation was conceptualised (and later operationalised) by Kohli \& Jaworski (1990), in which they described that the construct is comprised of: generation, dissemination, and responsiveness activities. That is, intelligence generation concerns the collection of 
information linked with their customers and competitors (Jaworski \& Kohli, 1993), intelligence dissemination relates the ways that managers and employees process information about their customers and competitors (Cadogan, 2003), and intelligence responsiveness surrounds how businesses act in response to the information they have collected and processed about their customers and competitors (Ozturan et al., 2014). Importantly, market-oriented behaviours are organisation-wide activities, involving all members of staff within a business (Cadogan, Souchon, \& Procter, 2008).

Although market-oriented behaviours have been conceptualised and operationalised as a three-component variable (generation, dissemination, and responsiveness activities) (Kohli \& Jaworski, 1990; Jaworski \& Kohli, 1993), certain scholars have focused on intelligence responsiveness, as the most critical market-oriented behaviour used to implement the marketing concept (reference withheld). Intelligence responsiveness concerns the processes that managers and employees use to respond to information they generated and disseminated within their companies (Souchon, Cadogan, Procter, \& Dewsnap, 2004). If businesses have the resources and capabilities that are needed to respond to customers' wants and needs, it is this market-oriented behaviour that is most likely to have a positive impact on company performance (Morgan, Vorhies, \& Mason, 2009). As such, intelligence responsiveness activities are likely to be the processes that create superior value for customers (Ozturan et al., 2014; Wei, Samiee, \& Lee, 2014). International forms of market orientation follow in the next section.

\section{International forms of market orientation}

Both corporate cultural and behavioural approaches of market orientation have been predominately-studied in domestic contexts, in which organisations attempt to create 
value for their customers in their home country (Rukert, 1992; Greenley, 1995; Hult \& Ketchen Jr., 2001; Grinstein, 2008; Baker \& Sinkula, 2009; Ngo \& O’Cass, 2012; Crick, 2018). That said, in the 1990 s, work began to emerge on market orientation in an exporting context to examine how firms can create value for their customers under an internationalised business model (Cadogan, 2003). Cadogan \& Diamantopoulos (1995) integrated the work of Kohli \& Jaworski (1990) and Narver \& Slater (1990) and linked such conceptualisations with the international marketing literature to understand how market orientation might exist for internationalised companies. They found that there is a reasonable degree of conceptual and operational overlap between the MARKOR and MKTOR scales, for which market orientation concerns a set of information processing activities, allowing the two approaches to be merged (see Diamantopoulos \& Cadogan, 1996).

Cadogan, Diamantopoulos, \& de Mortanges (1999) developed and validated the export market orientation scale, which was comprised of export-oriented: generation, dissemination, and responsiveness activities. In the 2000s, export market orientation was studied in greater depth, with various academics finding that by engaging in export-oriented market-oriented behaviours, companies are likely to obtain higherlevels of export performance, such as greater sales in export markets (Rose \& Shoham, 2002; Makri, Theodosiou, \& Katsikea, 2017). Despite a behavioural approach being taken (Cadogan, Paul, Salminen, Puumalainen, \& Sundqvist, 2001), the conceptualisation and operationalisation contains elements of the work of Kohli \& Jaworski (1990) and Narver \& Slater (1990). Export market orientation is focused on exporting, as an internationalisation strategy, not other market entry modes, like franchising or strategic alliances (Tapan, 2001; Alves, \& Meneses, 2015). Some other forms of market orientation are highlighted in the next section. 


\section{Other forms of market orientation}

While Kohli \& Jaworski's (1990) and Narver \& Slater's (1990) respective studies are the main approaches of studying the market orientation construct, some marketing academics have developed other conceptualisations and operationalisations. For instance, Ruekert (1992) examined market orientation under an "organisational strategy" perspective, in which the adopted conceptualisation and operationalisation was comprised of three dimensions, namely, firms': use of information, development of a market-oriented strategy, and implementation of a market-oriented strategy. Ruekert's (1992) assessment of the market orientation construct was like Kohli \& Jaworski's (1990) and Narver \& Slater's (1990) articles, as it was linked with market orientation being a set of organisation-wide information-processing activities, whereby, managers and employees collect and respond to information about their customers and competitors and use such information to create a superior customer value provision to rival firms (Cadogan, 2003). Yet, Ruekert (1992) took an organisational strategy-based perspective, as opposed to corporate cultural or behavioural views of market orientation.

Later in the 1990s, Gray, Matear, Boshoff, \& Matheson (1998) developed and validated a new measure of market orientation by integrating aspects of the MKTOR and MARKOR scales (see Jaworski \& Kohli, 1993; Kohli et al., 1993; Narver \& Slater, 1990). After a series of multivariate statistical techniques, these authors found that market orientation is a five-component variable, comprised of: a customer orientation, a competitor orientation, inter-functional coordination (the facets of the MKTOR scale), responsiveness (an element of the MARKOR scale), and a profit emphasis (based on Narver \& Slater, 1990). It is argued that Gray et al.'s (1998) measure of market orientation integrated corporate cultural and behavioural approaches without showing 
sufficient evidence of how market orientation exists. That is, these authors did not fullyexplain how managers and employees might implement the marketing concept through these different facets of market orientation. Hence, this could be a reason why this scale has not been a popular operationalisation within the existing body of knowledge (reference withheld).

It is important to note that market orientation has been well-explored in the marketing literature, with numerous authors examining the antecedents and consequences of the construct (Hult \& Ketchen Jr., 2001; Ellis, 2006; Homburg, Jozic, \& Kuehnl, 2017). However, although there are a range of conceptualisations and operationalisations of market orientation available to marketing scholars, the two most popular measures are the MKTOR and MARKOR scales (see Narver \& Slater, 1990; Jaworski \& Kohli, 1993; Kohli et al., 1993). Furthermore, as mentioned earlier, the export market orientation scale has been used to examine market-oriented activities for organisations competing on an international-level (Cadogan et al., 2002; Murray et al., 2011). Other conceptualisations of market orientation have been developed, but have been used to a far less extent than these three approaches (e.g., Deshpande, Farley, \& Webster Jr., 1989; Deng \& Dart, 1994). Indeed, no major measures of market orientation have been developed since the 1990s (Lafferty \& Hult, 2001). The dimensionality of the market orientation construct is discussed as follows.

\section{Dimensionality of the market orientation construct}

The dimensionality of a construct concerns whether a variable is comprised of one or multiple facets (Hulland, 1999). For example, the competitive business environment has been conceptualised and operationalised as a multi-dimensional construct, as the external market-level forces that affect organisations are not contained to one issue 
(e.g., competitiveness) (Porter, 1985; Kirca et al., 2005; Vermeulen, 2018). That is, scholars have explored the competitive business environment as a multi-dimensional construct, comprised of factors, such as: competitive intensity, technological turbulence, and market dynamism (Jaworski \& Kohli, 1993; Slater \& Narver, 1994; Cadogan et al., 2003). Hence, recognising that a construct is multi-dimensional is critical to understanding the meaning (Churchill Jr., 1979). If academics only study one facet of a multi-dimensional construct, arguably, they are limiting themselves to understanding a fraction of the variable, for which they should consider all its dimensions (where possible) (Bagozzi \& Edwards, 1998). Therefore, it is vital that researchers should appreciate the multi-dimensionality of the market orientation construct (see Cadogan, 2003).

As indicated in this current article, there are multiple ways to study market orientation, like: under a corporate cultural lens (as per Harris, 1998; Homburg \& Pflesser, 2000), as a set of firm-level behaviours (see Kohli \& Jaworski, 1990), as well as international forms of the construct (e.g., Cadogan et al., 2009). Indeed, as also noted in this article, despite the differences between the various conceptualisations and operationalisations of market orientation, there are conceptual and operational overlaps (Cadogan \& Diamantopoulos, 1995). That is, all the major market orientation approaches concern the implementation of the marketing concept and the organisation-wide creation of customer value (Kirca et al., 2005; Ellis, 2006). Consequently, regardless of how scholars choose to explore market orientation, they should always highlight its purpose in being a way of creating a superior customer value provision than competitors (Lafferty \& Hult, 2001; Cadogan, 2003). By engaging in market orientation, there is likely to be a positive relationship with company 
performance (e.g., sales) (Hurley \& Hult, 1998; Kirca et al., 2005; Kumar et al., 2011; Murray et al., 2011).

Indeed, most authors have agreed that market orientation is a set of information processing activities, whereby, firms collect and analyse information about their customers and competitors and respond to such information to implement the marketing concept (see Narver \& Slater, 1990; Ruekert, 1992; Jaworski \& Kohli, 1993; Cadogan et al., 2002; Ozturan et al., 2014). However, it is clear that market orientation is a multi-dimensional construct, comprised of different facets, such as: the generation of, dissemination of, and responsiveness to market intelligence (under the MARKOR scale) (see Jaworski \& Kohli, 1993; Kohli et al., 1993) or alternatively: a competitor orientation, a customer orientation, and inter-functional coordination (as per the MKTOR scale) (see Narver \& Slater, 1990). Indeed, the dimensionality of the market orientation construct can be divided into additional facets when considering the different forms of individual behaviours, such as intelligence responsiveness, which could include several different sub-components to determine the quality of these firmlevel activities (see Cadogan et al., 2008).

Specifically, Cadogan et al. (2008) examined the quality of market-oriented behaviours. These authors argued that under Jaworski \& Kohli's (1993) MARKOR scale, the components of the measure did not fully-capture what it means to be marketoriented (generation, dissemination, and responsiveness activities). Cadogan et al. (2008) developed a validated some new measurement scales, examining the quality of market-oriented behaviours through a formative index construction. For instance, Cadogan et al. (2008) found that intelligence responsiveness is comprised of multiple sub-dimensions, namely: organisation-wide responsiveness, speed of responsiveness, risk-taking in responsiveness, and formalisation of responsiveness. 
Likewise, they argued that intelligence generation and intelligence dissemination activities contain different facets, highlighting that not only is the market orientation construct multi-dimensional, but there could be additional dimensions that seminal researchers have not considered (e.g., Jaworski \& Kohli, 1993; Kohli \& Jaworski, 1990; Kohli et al., 1993).

Certain scholars have conceptualised and operationalised market orientation as a unidimensional construct, in which only one facet has been considered. For instance, Deshpande \& Farley (1998, p. 213) defined market orientation as "the set of crossfunctional processes and activities directed at creating and satisfying customers through a continuous needs-assessment." When measuring market orientation, these authors focused on the customer orientation dimension of the construct. Albeit important, customer orientation is only one aspect of market orientation (Narver \& Slater, 1990; Slater \& Narver, 1998; Ellis, 2006). That is, firms might be aware of the wants and needs of their customers, but such information is redundant if they do not possess insights into their competitors' strengths and weakness and key activities (a competitor orientation) (Armstrong \& Collopy, 1996; O’Dwyer \& Gilmore, 2018). Likewise, if departmental functions cannot communicate and cooperate, so that managers and employees work to create value for their customers (inter-functional coordination), market orientation does not exist (Ruekert \& Walker Jr., 1987; Menguc \& Auh, 2006; Verhoef \& Leeflang, 2009; Feng et al., 2015).

Connor (1999) examined the role of a customer orientation, as an element of a marketoriented business strategy. In this paper, Connor (1999, p. 1160) highlighted that "a paradox is implied in the distinction between the customer-led and the market-led orientation. If market orientation leads to competitive success, this means greater market share, but this means satisfying more customers, today and in the future." That 
is, Connor (1999) focused on a customer orientation being the most critical factor in a market-oriented corporate culture, as it demonstrates the degree to which managers and employees believe that creating value for customers is a performance-driving activity. Slater \& Narver (1999) responded to Connor (1999), whereby, they agreed that a firm's customer orientation is a highly-important activity, as it does indeed evaluate the magnitude of knowledge of customers' wants and needs. However, Slater \& Narver (1999) continued to argue that a firm's customer orientation is only one dimension of market orientation, for which it is equally important to consider a competitor orientation and the degree of inter-functional coordination. Hence, Slater \& Narver (1999) were advocates for a multi-dimensional measure of market orientation (see also Slater \& Narver, 1998).

The uni-dimensionality of the market orientation construct (as per Deshpande \& Farley, 1998) has been incorporated by a range of authors in the more recent literature. As an illustration, Morgan et al. (2015) examined the interplay between market orientation and entrepreneurial orientation and its effect on new product development performance. Interestingly, these authors conceptualised and operationalised entrepreneurial orientation as a three-component variable, comprised of: innovativeness, proactiveness, and risk-taking behaviours (as per Lumpkin \& Dess, 1996; Morrish, 2011; Crick, 2018). Yet, when conceptualising and operationalising the market orientation construct, these authors did not consider its multi-dimensionality. Consequently, while Morgan et al.'s (2015) provided some interesting insights into the dark-side of the interplay between market orientation and entrepreneurial orientation, it is questionable about the degree to which these authors were truly examining the full essence of the market orientation construct. Some directions for future research follow in the next section. 


\section{Directions for future research}

Based on the themes of this literature review, it is recommended that marketing academics should be careful as to how they conceptualise and operationalise the market orientation construct. That is, scholars should be aware that market orientation can: be a corporate culture (as per Harris, 1998; Slater \& Narver, 1999), be a set of firm-level behaviours (Kohli \& Jaworski, 1990; Cadogan, 2003), or appear in other forms (see Ruekert, 1992). Henceforth, when contributing to the market orientation literature, scholars should use an appropriate assessment of the construct, depending on the issues that they are studying. For example, if researchers are studying a research gap linked with organisational cultures, they are better-served if they investigate corporate cultural forms of market orientation (e.g., the MKTOR scale) (see Narver \& Slater, 1990; Homburg \& Pflesser, 2000; Harris \& Ogbonna, 2001). Likewise, when exploring the behavioural forms of market orientation, marketing scholars should use the MARKOR scale, as this captures the market orientation construct as a set of firm-level behaviours (see Jaworski \& Kohli, 1993; Kohli et al., 1993).

Additionally, the dimensionality of the market orientation construct is a highly-important issue, as it is clear from the extant literature that market orientation is a multidimensional variable (e.g., Kohli \& Jaworski, 1990; Gray et al., 1998; Slater \& Narver, 1999; Jones \& Rowley, 2011). Although uni-dimensional measures have been used by certain scholars (e.g., Deshpande \& Farley, 1998; Morgan et al., 2015), these approaches have been significantly less common that multi-dimensional assessments of market orientation (as per Ruekert, 1992; Hult \& Ketchen Jr., 2001; Hult et al., 2005; Cadogan et al., 2009). By using uni-dimensional measures of market orientation, it is suggested that scholars have not appreciated the full essence of the construct. Therefore, in future research, it is recommended that scholars should consider the 
multi-dimensionality of the market orientation construct, whether they are studying it as a corporate culture (Homburg \& Pflesser, 2000; Harris \& Ogbonna, 2001) or a set of firm-level behaviours (Lafferty \& Hult, 2001; Cadogan et al., 2002; Jaworski \& Kohli, 1993).

If marketing scholars are interested in conceptualising and operationalising market orientation as a uni-dimensional construct, it is strongly-argued that this cannot be achieved without conceptual and operational problems (as described above) (Cadogan \& Diamantopoulos, 1995). Nevertheless, certain scholars have attempted to study market orientation as a uni-dimensional variable (Deshpande \& Farley, 1998; Morgan et al., 2015). It is strongly-advised that marketing academics should not use these multi-dimensional measures, but they are perfectly entitled to explore certain aspects of market orientation. For example, if scholars are interested in the performance consequences of market-oriented behaviours, they could investigate the role of intelligence responsiveness as a critical market-oriented behaviour. As mentioned earlier, intelligence responsiveness helps business to implement the marketing concept to a greater the degree than intelligence generation or intelligence dissemination activities (Souchon et al., 2004; Ozturan et al., 2014; Wei et al., 2014). If researchers take this approach, they should only make inferences about their chosen dimension of market orientation, not the entire construct.

As noted throughout this article, there are major conceptual and operational overlaps between the different approaches of market orientation (Cadogan \& Diamantopoulos, 1995; Cadogan, 2003; Jones \& Rowley, 2011). To emphasise some important points, the market orientation construct has been conceptualised and operationalised in numerous capacities, but the two most common approaches have been under corporate cultural (Slater \& Narver, 1998; Homburg \& Pflesser, 2000; Harris \& 
Ogbonna, 2001) and behavioural lenses (Jaworski \& Kohli, 1993; Cadogan et al., 2008). Further, other research has been undertaken on other forms of market orientation, such as Ruekert's (1992) organisational strategy perspective and export market orientation (Cadogan et al., 1999; Rose \& Shoham, 2002; Murray et al., 2011). While scholars have used different tools to develop and validate these forms of market orientation, they have a prominent common factor, involving firms collecting and responding to information about the ways to create a superior degree of customer value to competitors (Figure 1).

\section{[Insert Figure 1 about here]}

Marketing scholars should use the information in Figure 1 to understand how market orientation can exist in numerous forms. In short, academics are recommended to conceptualise and operationalise market orientation under a corporate cultural or behavioural approach (among other forms), while considering the construct's multidimensionality. Further, Jones \& Rowley (2011, p. 31) stated that future research should undertake "a comparison of the dimensions identified in each of the orientations of: a market orientation, a customer orientation, an innovation orientation, and an entrepreneurial orientation." As such, this current article responds to Jones \& Rowley's (2011) call for research on different strategic orientations, but adds that the dimensionality of each construct (especially market orientation) is a highly-important issue. Building upon Jones \& Rowley's (2011) study is also critical, as it is important to differentiate between the multiple assessments of the market orientation construct, such as a customer orientation (as per Narver \& Slater, 1990), vis-à-vis- behavioural forms of market orientation (see Jaworski \& Kohli, 2017). Some conclusions are offered in the following section. 


\section{Conclusions}

The objective of this paper was to help marketing scholars to appreciate the dimensionality of the market orientation construct. To achieve this objective, a review of the marketing literature was undertaken to understand the different approaches to studying market orientation and the dimensions of the various forms of the construct. As such, the following conclusions are made. First, it is concluded that market orientation can be explored as a corporate culture as a set of firm-level behaviours (among other forms). Second, it is also concluded that regardless of how market orientation is investigated, academics should appreciate that it is a multi-dimensional construct. Third, it is finally concluded that uni-dimensional measures of market orientation do not capture the essence of the construct. Thus, scholars should use multi-dimensional measures to fully-appreciate its meaning. Hence, this literature review provides scope to help marketing academics to appreciate the different forms of market orientation and the multiple dimensions within these approaches. 


\section{References}

Alves, J., \& Menses, R. (2015). Partner selection in co-opetition: A three step model. Journal of Research in Marketing and Entrepreneurship, 17(1), 23-35.

Armstrong, J. S., \& Collopy, F. (1996). Competitor orientation: Effects of objectives and information on managerial decisions and profitability. Journal of Marketing Research, 33(2), 188-199.

Atuahene-Gima, K., Slater, S. F., \& Olson, E. M. (2005). The contingent value of responsive and proactive market orientations for new product program performance. Journal of Product Innovation Management, 22(6), 464-482.

Bagozzi, R. P., \& Edwards, J. R. (1998). A general approach for representing constructs in organizational research. Organizational Research Methods, 1(1), 45-87.

Baker, W. E., \& Sinkula, J. M. (2009). The complementary effects of market orientation and entrepreneurial orientation on profitability in small businesses. Journal of Small Business Management, 47(4), 443-464.

Beneke, J., Blampied, S., Dewar, N., \& Soriano, L. (2016). The impact of market orientation and learning orientation on organisational performance: A study of small to medium-sized enterprises in Cape Town, South Africa. Journal of Research in Marketing and Entrepreneurship, 18(1), 90-108.

Blois, K. J. (1980). The manufacturing/marketing orientation and its information needs. European Journal of Marketing, 14(5-6), 354-364.

Boso, N., Story, V. M., \& Cadogan, J. W. (2013). Entrepreneurial orientation, market orientation, network ties, and performance: Study of entrepreneurial firms in a developing economy", Journal of Business Venturing, 28(6), 708-727.

Bund, H., \& Carroll, J. W. (1957). The changing role of the marketing function. Journal of Marketing, 21(3), 268-325.

Cadogan, J. W. (2003). Multiple perspectives on market orientation's domain specification: implications for theory development and knowledge accumulation. In S. Hart (ed.). Marketing Changes (pp. 95-123 and pp. 325-328). London: Thompson Business Press.

Cadogan, J. W., \& Diamantopoulos, A. (1995). Narver and Slater, Kohli and Jaworski and the market orientation construct: Integration and internationalization. Journal of Strategic Marketing, 3(1), 41-60.

Cadogan, J. W., Cui, C. C. \& Li, E. K. Y. (2003). Export market-oriented behavior and export performance: The moderating roles of competitive intensity and technological turbulence. International Marketing Review, 20(5), 493-513.

Cadogan, J. W., Diamantopoulos, A., \& de Mortanges, C. P. (1999). A measure of export market orientation: Scale development and cross-cultural validation. Journal of International Business Studies, 30(4), 689-707.

Cadogan, J. W., Diamantopoulos, A., \& Siguaw, J. A. (2002). Export market-oriented activities: Their antecedents and performance consequences. Journal of International Business Studies, 33(3), 615-626. 
Cadogan, J. W., Kuivalainen, O., \& Sundqvist, S. (2009). Export market-oriented behavior and export performance: Quadratic and moderating effects under differing degrees of market dynamism and internationalization. Journal of International Marketing, 17(4), 71-89.

Cadogan, J. W., Paul, N. J., Salminen, R. T., Puumalainen, K., \& Sundqvist, S. (2001). Key antecedents to export market-oriented behaviors: A cross-national empirical examination. International Journal of Research in Marketing, 18(3), 261-282.

Cadogan, J. W., Souchon, A. L. and Procter, D. B. (2008). The quality of marketoriented behaviors: Formative index construction. Journal of Business Research, 61(12), 1263-1277.

Carpenter, G. S. (2017). Market orientation: reflections on field-based, discoveryoriented research. AMS Review, 7(1-2), 13-19.

Chaston, I. (1997). Small firm performance: Assessing the interaction between entrepreneurial style and organizational structure. European Journal of Marketing, 31(11-12), 814-831.

Churchill Jr., G. A. (1979). A paradigm for developing better measures of marketing constructs. Journal of Marketing Research, 16(1), 64-73.

Covin, J. G., \& Miller, D. (2018). International entrepreneurial orientation: Conceptual considerations, research themes, measurement issues, and future research directions. Entrepreneurship Theory and Practice, 38(1), 11-44.

Covin, J. G., \& Slevin, D. P. (1989). Strategic management of small firms in hostile and benign environments. Strategic Management Journal, 10(1), 75-87.

Covin, J. G., \& Wales, W. J. (2018). Crafting high-impact entrepreneurial orientation research: Some suggested guidelines. Entrepreneurship Theory and Practice (Forthcoming).

Connor, T. (1999). Customer-led and market-oriented: A matter of balance. Strategic Management Journal, 20(12), 1157-1163.

Crick, J. M. (2018). The facets, antecedents and consequences of coopetition: An entrepreneurial marketing perspective. Qualitative Market Research: An International Journal, 21(2), 253-272.

Crick, J. M., \& Crick, D. (2018). Angel investors' predictive and control funding criteria: The importance of evolving business models. Journal of Research in Marketing and Entrepreneurship, 20(1), 34-56.

De La Torre, J., \& Toyne, B. (1978). Cross-national managerial interaction: A conceptual model. Academy of Management Review, 3(1), 462-474.

Deng, S., \& Dart, J. (1994). Measuring market orientation: A multi-factor, multi-item approach. Journal of Marketing Management, 10(8), 725-742.

Deshpande, R., \& Farley, J. U. (1998). Measuring market orientation: Generalization and synthesis. Journal of Market-Focused Management, 2(3), 213-232.

Deshpande, R., Farley, J. U., \& Webster Jr., F. E. (1993). Corporate culture, customer orientation and innovativeness. Journal of Marketing, 57(1), 23-37. 
Diamantopoulos, A., \& Cadogan, J. W. (1996). Internationalizing the market orientation construct: An in-depth interview approach. Journal of Strategic Marketing, 4(1), 23-52.

Diamantopoulos, A., \& Hart, S. (1993). Linking market orientation and company performance: Preliminary evidence on Kohli and Jaworski's framework. Journal of Strategic Marketing, 1(2), 93-121.

Dickinson, R., Herbst, A., \& O'Shaughnessy, J. (1986). Marketing concept and customer orientation. European Journal of Marketing, 20(1), 18-23.

Ellis, P. D. (2006). Market orientation and performance: A meta-analysis and crossnational comparisons. Journal of Management Studies, 43(5), 1089-1107.

Fang, S. R., Chang, E., Ou, C-C., \& Chou, C-H. (2014). Internal market orientation, market capabilities and learning orientation. European Journal of Marketing, 48(2), 170-192.

Felton, A. P. (1959). Making the marketing concept work. Harvard Business Review, $37(5), 55-65$.

Feng, H., Morgan, N. A., \& Rego, L. L. (2015). Marketing department power and firm performance. Journal of Marketing, 79(5), 1-20.

Gaddefors, J., \& Anderson, A. R. (1998). Market creation: The epitome of entrepreneurial marketing practices. Journal of Research in Marketing and Entrepreneurship, 10(1), 19-39.

Goebel, D. J., Marshall, G. W., \& Locander, W. B. (1994). Activity-based costing: Accounting for a market orientation. Industrial Marketing Management, 27(6), 497-510.

Gounaris, S., Vassilikopoulou, A., \& Chatzipanagiotou, K. C. (2010). Internal market orientation: A misconceived aspect of marketing theory. European Journal of Marketing, 44(11-12), 1667-1699.

Gray, B. J., Matear, S., Boshoff, C., \& Matheson, P. (1998). Developing a better measure of market orientation. European Journal of Marketing, 32(9-10), 884903.

Greenley, G. E. (1995). Market orientation and company performance: Empirical evidence from UK companies. British Journal of Management, 6(1), 1-13.

Grinstein, A. (2008). The effect of market orientation and its components on innovation consequences: A meta-analysis. Journal of the Academy of Marketing Science, 36(2), 166-173.

Hamley, T. C., \& Budd, W. F. (1986). Antarctic iceberg distribution and dissolution. Journal of Glaciology, 32(111), 242-251.

Han, J. K., Kim, N., \& Srivastava, R. K. (1998). Market orientation and organizational performance: Is innovation a missing link? Journal of Marketing, 62(4), 30-45.

Harris, L. C. (1998). Cultural domination: The key to market-oriented culture? European Journal of Marketing, 32(3-4), 354-373. 
Harris, L. C., \& Ogbonna, E. (2001). Leadership style and market orientation: An empirical study. European Journal of Marketing, 35(5-6), 744-764.

Henderson, S. (1998). No such thing as market orientation: A call for no more papers. Management Decision, 36(9), 598-609.

Hills, G. E., \& Hultman, C. M. (2011). Research in marketing and entrepreneurship: A retrospective viewpoint. Journal of Research in Marketing and Entrepreneurship, 13(1), 8-17.

Hills, G. E., \& LaForge, R. W. (1992). Research at the marketing interface to advance entrepreneurship theory. Entrepreneurship Theory and Practice, 16(3), 33-60.

Hills, G. E., Hultman, C. M., \& Miles, M. P. (2008). The evolution and development of entrepreneurial marketing. Journal of Small Business Management, 46(1), 99112.

Hodgkinson, I. R., Hughes, P., \& Hughes, M. (2012). Absorptive capacity and market orientation in public service provision. Journal of Strategic Marketing, 20(3), 211229.

Homburg, C., \& Pflesser, C. (2000). A multiple-layer model of market-oriented organizational culture: Measurement issues and performance outcomes. Journal of Marketing Research, 37(4), 449-462.

Homburg, C., Jozic, D., \& Kuehnl, C. (2017). Customer experience management: Toward implementing an evolving marketing concept. Journal of the Academy of Marketing Science, 45(3), 377-401.

Hulland, J. (1999). Use of partial least squares (PLS) in strategic management research: A review of four recent studies. Strategic Management Journal, 20(2), 195-204.

Hult, G. T. M., \& Ketchen Jr., D. J. (2001). Does market orientation matter? A test of the relationship between positional advantage and performance. Strategic Management Journal, 22(9), 899-906.

Hult, G. T. M., \& Ketchen Jr., D. J. (2017). Disruptive marketing strategy. AMS Review, $7(1-2), 20-25$.

Hult, G. T. M., Ketchen Jr., D. J., \& Slater, S. F. (2005). Market orientation and performance: An integration of disparate approaches. Strategic Management Journal, 26(12), 1173-1181.

Hunt, S. D., \& Morgan, R. M. (1994). The comparative advantage theory of competition. Journal of Marketing, 59(2), 1-15.

Hurley, R. F., \& Hult, G. T. M. (1998). Innovation, market orientation, and organizational learning: An integration and empirical examination. Journal of Marketing, 62(3), 42-54.

Jaakkola, E., \& Alexander, M. (2014). The role of customer engagement behavior in value co-creation: A service system perspective. Journal of Service Research, 17(3), 247-261. 
Jaworski, B. J., \& Kohli, A. K. (1993). Market orientation: Antecedents and consequences. Journal of Marketing, 57(3), 53-70.

Jaworski, B. J., \& Kohli, A. K. (2017). Conducting field-based, discovery-oriented research: Lessons from our market orientation research experience. AMS Review, 7(1-2), 4-12.

Jones, D. G. B., \& Shaw, E. H. (2018). Avoiding academic irrelevance in the marketing discipline: The promise of the history of marketing thought. Journal of Marketing Management, 34(1-2), 52-62.

Jones, R., \& Rowley, J. (2009). Presentation of a generic EMICO framework for research exploration of entrepreneurial marketing in SMEs. Journal of Research in Marketing and Entrepreneurship, 11(1), 5-21.

Jones, R., \& Rowley, J. (2011). Entrepreneurial marketing in small businesses: A conceptual exploration. International Small Business Journal, 29(1), 25-36.

Katsikeas, C. S., Morgan, N. A., Leonidou, L. C., \& Hult, G. T. M. (2016). Assessing performance outcomes in marketing. Journal of Marketing, 80(2), 1-20.

Kirca, A. H., Jayachandran, S., \& and Bearden, W. O. (2005). Market orientation: A meta-analytic review and assessment of its antecedents and impact on performance. Journal of Marketing, 69(2), 24-41.

Kohli, A. K., \& Jaworski, B. J. (1990). Market orientation: The construct, research propositions, and managerial implications. Journal of Marketing, 54(2), 1-18.

Kohli, A. K., Jaworski, B. J., \& Kumar, A. (1993). MARKOR: A measure of market orientation. Journal of Marketing Research, 30(4), 467-477.

Kumar, V., \& Reinartz, W. (2016). Creating enduring customer value. Journal of Marketing, 80(6), 36-68.

Kumar, V., Jones, E., Venkatesan, R., \& Leone, R. P. (2011). Is market orientation a source of sustainable competitive advantage or simply the cost of competing? Journal of Marketing, 75(1), 16-30.

Lafferty, B. A., \& Hult, G. T. M. (2001). A synthesis of contemporary market orientation perspectives. European Journal of Marketing, 35(1-2), 92-109.

Lemon, K. N., \& Verhoef, P. C. (2016). Understanding customer experience throughout the customer journey. Journal of Marketing, 80(6), 69-96.

Lumpkin, G. T., \& Dess, G. G. (1996). Clarifying the entrepreneurial orientation construct and linking it to performance. Academy of Management Review, 21(1), 135-172.

McNamara, C. P. (1972). The present status of the marketing concept. Journal of Marketing, 36(1), 50-57.

Makri, K., Theodosiou, M., \& Katsikea, E. (2017). An empirical investigation of the antecedents and performance outcomes of export innovativeness. International Business Review, 26(4), 628-639.

Maltz, E., \& Kohli, A. K. (1996). Market intelligence dissemination across functional boundaries. Journal of Marketing Research, 33(1), 47-61. 
Matsuno, K., Mentzer, J. T., \& Ozsomer, A. (2014). The effects of entrepreneurial proclivity and market orientation on business performance. Journal of Marketing, 66(3), 18-32.

McGee, J. E., \& Peterson, M. (2018). The long-term impact of entrepreneurial selfefficacy and entrepreneurial orientation on venture performance. Journal of Small Business Management (Forthcoming).

Menguc, B., \& Auh, S. (2006). Creating a firm-level dynamic capability through capitalizing on market orientation and innovativeness. Journal of the Academy of Marketing Science, 34(1), 63-73.

Miles, M. P., \& Arnold, D. R. (1991). The relationship between marketing orientation and entrepreneurial orientation. Entrepreneurship Theory and Practice, 15(4), 49-66.

Miles, M. P., Gilmore, A., Harrigan, P., Lewis, G., \& Sethna, Z. (2015). Exploring entrepreneurial marketing. Journal of Strategic Marketing, 23(2), 94-111.

Morgan, N. A. (2012). Marketing and business performance. Journal of the Academy of Marketing Science, 40(1), 102-119.

Morgan, N. A., Vorhies, D. W., \& Mason, C. H. (2009). Market orientation, marketing capabilities, and firm performance. Strategic Management Journal, 30(8), 909920.

Morgan, T., Anokhin, S., Kretinin, S., \& Frishammar, J. (2015). The dark-side of the entrepreneurial orientation and market orientation interplay: A new product development perspective. International Small Business Journal, 33(7), 731-751.

Morrish, S. C. (2011). Entrepreneurial marketing: A strategy for the twenty-first century? Journal of Research in Marketing and Entrepreneurship, 13(2), 110119.

Morrish, S. C., Miles, M. P., \& Deacon, J. H. (2010). Entrepreneurial marketing: Acknowledging the entrepreneur and customer-centric interrelationship. Journal of Strategic Marketing, 18(4), 303-316.

Morris, M., Schindehutte, M., \& LaForge, R. W. (2002). Entrepreneurial marketing: A construct for integrating emerging entrepreneurship and marketing perspectives. Journal of Marketing Theory and Practice, 10(4), 1-19.

Murray, J. Y., Gao, G. Y., \& Kotabe, M. (2011). Market orientation and performance of export ventures: The process through marketing capabilities and competitive advantages. Journal of the Academy of Marketing Science, 39(2), 252-269.

Narver, J. C., \& Slater, S. F. (1990). The effect of a market orientation on business profitability. Journal of Marketing, 54(4), 20-35.

Ngo, L. V., \& O'Cass, A. (2012). Performance implications of market orientation, marketing resources, and marketing capabilities. Journal of Marketing Management, 28(1-2), 173-187.

Nonaka, I. (1994). A dynamic theory of organizational knowledge creation. Organization Science, 5(1), 14-37. 
O'Cass, A. (2001). Political marketing: an investigation of the political marketing concept and political market orientation in Australian politics. European Journal of Marketing, 35(9-10), 1003-1025.

O'Cass, A., \& Morrish, S. C. (2016). Anatomy of entrepreneurial marketing. Journal of Strategic Marketing, 24(1), 2-4.

O'Dwyer, M., \& Gilmore, A. (2018). Competitor orientation in successful SMEs: An exploration of the impact on innovation. Journal of Strategic Marketing (Forthcoming).

O'Dwyer, M., Gilmore, A., \& Carson, D. (2009). Innovative marketing in SMEs: An empirical study. Journal of Strategic Marketing, 17(5), 383-396.

Olson, E. M., Slater, S. F., Hult, G. T. M., \& Olson, K. M. (2018). The application of human resource management policies within the marketing organization: The impact on business and marketing strategy implementation", Industrial Marketing Management, 69(1), 62-73.

Ozturan, P., Ozsomer, A., \& Pieters, A. (2014). The role of market orientation in advertising spending during economic collapse: The case of Turkey in 2001. Journal of Marketing Research, 51(2), 139-152.

Palmer, I., \& Dunford, R. (1994). Conflicting uses of metaphors: Reconceptualizing their use in the field of organizational change. Academy of Management Review, 21(3), 691-717.

Parasuraman, A. (1997). Reflections on gaining competitive advantage through customer value. Journal of the Academy of Marketing Science, 25(2), 154-161.

Payne, A. F., \& Holt, S. (2001). Diagnosing customer value: integrating the value process and relationship marketing. British Journal of Management, 12(2), 159182.

Piercy, N. F. (1987). The marketing budgeting process: Marketing management implications. Journal of Marketing, 51(4), 45-59.

Porter, M. E. (1985). Competitive advantage: Creating and sustaining superior performance. New York: Free Press.

Rauch, A., Wiklund, J., Lumpkin, G. T., \& Frese, M. (2009). Entrepreneurial orientation and business performance: An assessment of past research and suggestions for the future. Entrepreneurship Theory and Practice, 33(3), 761-787.

Ray, G., Barney, J. B., \& Muhanna, W. A. (2004). Capabilities, business processes, and competitive advantage: Choosing the dependent variable in empirical tests of the resource-based view. Strategic Management Journal, 25(1), 23-37.

Rose, G. M., \& Shoham, A. (2002). Export performance and market orientation: Establishing an empirical link. Journal of Business Research, 55(3), 217-225.

Ruekert, R. W. (1992). Developing a market orientation: an organizational strategy perspective. International Journal of Research in Marketing, 9(3), 225-245. 
Ruekert, R. W., \& Walker Jr., O. C. (1987). Interactions between marketing and R\&D departments in implementing different business strategies. Strategic Management Journal, 8(3), 233-248.

Ryals, L. (2005). Making customer relationship management work: The measurement and profitable management of customer relationships. Journal of Marketing, 69(4), 252-261.

Slater, S. F. (1997). Developing a customer value-based theory of the firm. Journal of the Academy of Marketing Science, 25(2), 162-167.

Slater, S. F., \& Narver, J. C. (1994). Does competitive environment moderate the market orientation-performance relationship? Journal of Marketing, 58(1), 46-55.

Slater, S. F., \& Narver, J. C. (1998). Customer-led and market-oriented: Let's not confuse the two. Strategic Management Journal, 19(10), 1001-1006.

Slater, S. F., \& Narver, J. C. (1999). Market-oriented is more than being customerled. Strategic Management Journal, 20(12), 1165-1168.

Slater, S. F., \& Narver, J. C. (2000). Intelligence generation and superior customer value. Journal of the Academy of Marketing Science, 28(1), 120-127.

Sole, M. (2013). Entrepreneurial marketing: conceptual exploration and link to performance. Journal of Research in Marketing and Entrepreneurship, 15(1), 2338.

Souchon, A. L., Cadogan, J. W., Procter, D. B., \& Dewsnap, B. (2004). Marketing information use and organisational performance: The mediating role of responsiveness. Journal of Strategic Marketing, 12(4), 231-242.

Stokes, D. (2000). Putting entrepreneurship into marketing: The processes of entrepreneurial marketing. Journal of Research in Marketing and Entrepreneurship, 2(1), 1-16.

Sundqvist, S., Kylaheiko, K., Kuivalainen, O., \& Cadogan, J. W. (2012). Kirznerian and Schumpeterian entrepreneurial-oriented behavior in turbulent export markets. International Marketing Review, 29(2), 203-219.

Tapan, S. S. (2001). Entrepreneurial ventures and small business: An assessment of the entrepreneurial roles of the franchisor and the franchisee from an entrepreneurial school of strategy formation perspective. Journal of Research in Marketing and Entrepreneurship, 3(3), 123-138.

Thompson, M., \& Wildavsky, A. (1986). A cultural theory of information bias in organizations. Journal of Management Studies, 23(3), 273-286.

Verhoef, P. C., \& Leeflang, P. S. H. (2009). Understanding the marketing department's influence within the firm. Journal of Marketing, 73(2), 14-37.

Vermeulen, F. (2018). A basic theory of inheritance: how bad practice prevails. Strategic Management Journal, 39(6), 1603-1629.

Wei, Y. S., Samiee, S., \& and Lee, R. P. (2014). The influence of organic organizational cultures, market responsiveness, and product strategy on firm 
performance in an emerging market. Journal of the Academy of Marketing Science, 42(1), 49-70.

Wiklund, J., \& Shepherd, D. A. (2003). Knowledge-based resources, entrepreneurial orientation, and the performance of small and medium-sized businesses. Strategic Management Journal, 24(13), 1307-1314.

Wiklund, J., \& Shepherd, D. A. (2005). Entrepreneurial orientation and small business performance: A configurational approach. Journal of Business Venturing, 20(1), 71-91.

Wines, W. A., \& Hamilton, J. B. (2009). On changing organizational cultures by injecting new ideologies: The power of stories. Journal of Business Ethics, 89(3), 433-447.

Woodruff, R. B. (1997). Customer value: the next source for competitive advantage. Journal of the Academy of Marketing Science, 25(2), 139-153. 
Figure 1. The multiple forms of the market orientation construct.



